\title{
Bearing capacity of spudcan foundations in a spatially varying clayey seabed
}

\author{
$\mathrm{Li} \mathrm{Li}^{\mathrm{a}, \mathrm{b}}$, Jinhui Li ${ }^{\mathrm{a}, *}$, Jinsong Huang ${ }^{\mathrm{c}}$, Fu-Ping Gao ${ }^{\mathrm{d}, \mathrm{e}}$ \\ ${ }^{a}$ Department of Civil and Environmental Engineering, Harbin Institute of Technology Shenzhen Graduate School, Shenzhen 518055, China \\ b Shenzhen Institute of Geotechnical Investigation and Surveying, Shenzhen 518109, China \\ ${ }^{\mathrm{c}}$ ARC CoE for Geotechnical Science and Engineering, University of Newcastle, Newcastle 2308, Australia \\ ${ }^{\mathrm{d}}$ Key Laboratory for Mechanics in Fluid Solid Coupling Systems, Institute of Mechanics, Chinese Academy of Sciences, Beijing 100190, China \\ e School of Engineering Science, University of Chinese Academy of Sciences, Beijing 100049, China
}

\section{A R T I C L E I N F O}

Keywords:

Spudcan foundation

Spatial variability

Bearing capacity

Clay

Mobilized shear strength

\begin{abstract}
A B S T R A C T
Spudcan foundations are often pushed into a spatially varying non-homogeneous seabed to provide bearing capacity for a mobile jack-up platform. The natural variability of soil properties coupled with the complexity of loading conditions make determining the bearing capacity of spudcan foundations a challenging problem. A random finite element method is established to investigate the bearing capacity of a spudcan foundation embedded in a spatially varying clayey seabed when subjected to vertical, horizontal and moment loadings. A criterion is proposed for determining the characteristic value of the shear strength for the random seabed. Results indicate that the spatial variability in the clayey seabed significantly reduces the bearing capacity of a spudcan foundation. This reduction is more significant in the vertical bearing capacity than in the horizontal and moment bearing capacities. The mean bearing capacity is smaller for the clay with larger coefficient of variation of undrained shear strength. A characteristic value of mean minus a standard deviation of the undrained shear strength is capable to ensure the probability of failure is not greater than $5 \%$. This study provide an evaluation method for the spatial variability effect of a clayey seabed, paving the way for a costeffective design of spudcan foundations.
\end{abstract}

\section{Introduction}

Mobile jack-up drilling rigs play an important role in most offshore drilling operations in water depths up to $150 \mathrm{~m}$ (Hossain and Randolph, 2010). Spudcan foundations are often used to provide support to the jack-up drilling rigs by penetrating deeply into seabed clay (up to 3 diameters of spudcan) (Young et al., 1984; Menzies and Roper, 2008). The shear strength of seabed soils often varies spatially as a result of depositional and post-depositional process (Baecher and Christian, 2003; Lacasse and de Lamballerie, 1995). The soil properties at every location at a site, however, cannot be known perfectly because the site investigation is often limited in offshore areas. The lack of understanding on the complex soil conditions was found to be a crucial factor on the failures of platforms (Brennan et al., 2006; Gao et al., 2015).

In current guidelines, the uncertainties in soil properties, models and measurement errors are often accounted implicitly by a factor of safety. For example, API RP 2 GEO (2011) specifies a global factor of safety of 2.0 for the vertical bearing capacity of foundations. In the load and resistance factor design approaches, such as ISO 19905-1 (2012), a material factor of 1.5 is used to account for the uncertainties in soil properties. In addition to these factors, a characteristic shear strength is often taken as the mean value minus 1-3 times of the standard deviation (e.g., Wride et al., 1999). The level of reliability achieved using these factors, however, is still unclear. Study on the effect of the seabed spatial variability on a spudcan foundation is crucial for predicting the bearing capacity and determining the characteristic value of the soil strength (Ching and Phoon, 2011; Van Dijk and Yetginer, 2015).

Spudcan foundations are generally under combined vertical $(V)$, horizontal $(H)$ and moment $(M)$ loads due to the environmental loading (e.g., wind, waves and currents). Fig. 1 shows a platform, with spudcan foundations in spatially varying seabed, is subject to various loadings. The combined loading conditions, coupled with the uncertainty in the spatially varying seabed make the determination of the bearing capacity a very challenging problem.

This study aims to investigate the bearing capacity of a spudcan foundation embedded in a spatially variable clayey seabed when subjected to vertical, horizontal and moment loadings, and to explore the criterion to determine the characteristic shear strength of a random seabed clay. This study will help to pave the way to a cost-effective design of spudcan foundations in spatially varying seabed.

\footnotetext{
* Corresponding author.

E-mail address: jinhui.li@hit.edu.cn (J. Li).
} 


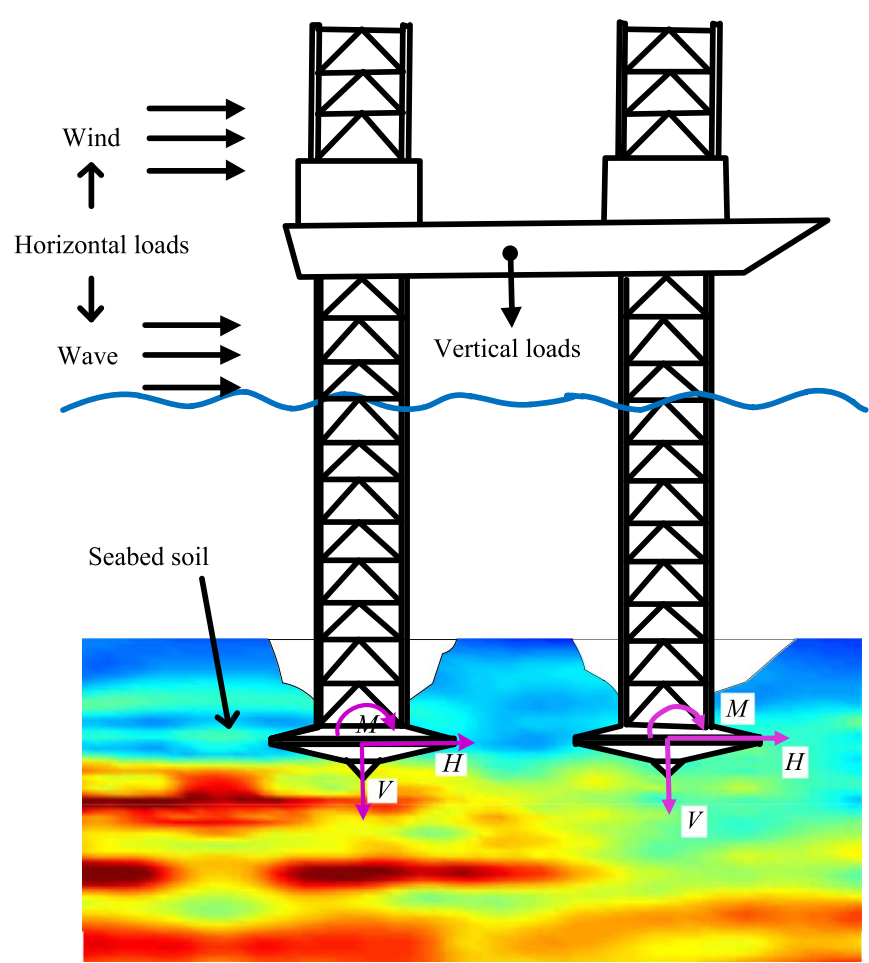

Fig. 1. Illustration of the jack-up platform in heterogeneous soil subjected to combined loading (red: stronger soil; blue: weaker soil).

\section{Spatially varying seabed}

The spatial variability of soil is often simulated by random fields described by a deterministic trend and a random residual (Vanmarcke, 1977). The deterministic trend is usually estimated by fitting mathematical functions to spatial data points. The random residuals around the trend are spatially correlated to one another in space. This correlation is generally represented by an autocorrelation function with a parameter called scale of fluctuation (see details in Baecher and Christian, 2003). The soil properties at two locations which are within the scale of fluctuation are closely related.

The spatial variation of the seabed soils has been investigated extensively in the North sea, the Gulf of Mexico and Offshore Australia (e.g., Tang, 1979; Lacasse and de Lamballerie, 1995; Cheon and Gilbert, 2014; Li et al., 2015b). Lacasse and Nadim (1996) found that the undrained shear strength of clay followed a normal or lognormal distribution with its coefficient of variation (i.e. the ratio between standard deviation and mean value) ranging between $5 \%$ and $35 \%$. The scale of fluctuation for seabed clay is different in different directions as a result of depositional process. The scale of fluctuation in horizontal direction ranged between $7 \mathrm{~m}$ and $9000 \mathrm{~m}$. In vertical direction the scale of fluctuation is much smaller, ranging between $0.4 \mathrm{~m}$ and $7.14 \mathrm{~m}$ (Li et al., 2016).

In this study, the undrained shear strength of the seabed clay $\left(s_{u}\right)$ is modeled as a stationary lognormal random field with mean value $\left(\mu_{\mathrm{s}}\right)$, standard deviation $\left(\sigma_{\mathrm{s}}\right)$, and scale of fluctuation (Griffiths and Fenton, 2001; Griffiths et al., 2002). The shear strength generally increases with the depth of the soil. The typical value of $10 \mathrm{kPa}$ at the seabed level is assumed to be the average undrained shear strength $\left(\mu_{\mathrm{s}}\right)$ for simplicity. To explore the influence of the coefficient of variation of the undrained shear strength (i.e., $\operatorname{COV}\left(s_{u}\right), \sigma_{\mathrm{s}} / \mu_{\mathrm{s}}$ ), five $\operatorname{COV}\left(s_{u}\right)$ (i.e., $0.1,0.2,0.3,0.4$ and 0.5$)$ are investigated. The exponential model is adopted to describe the autocorrelation function. The scale of fluctuation is chosen as $50.7 \mathrm{~m}$ in horizontal direction and $3.8 \mathrm{~m}$ in vertical direction, which is within the scope for the seabed clay (Phoon and Kulhawy, 1999; Lacasse and de Lamballerie, 1995). The effective unit weight of the soil is $7 \mathrm{kN} / \mathrm{m}^{3}$. The Poisson's ratio is set as 0.49 to simulate the undrained conditions of no volume change as well as to ensure computational stability. The Young's modulus $E$ is considered as perfectly correlated to the undrained shear strength with a constant ratio $\left(E / s_{\mathrm{u}}\right)$ of 500 . The clay is modeled as linear-elastic perfectly plastic material. Soil failure is determined by the Tresca criterion.

There are several random field generation methods available (see Fenton and Griffiths, 2008). The Karhunen-Loeve expansion method (e.g., Huang et al., 2013) is chosen because it has analytical solutions for the exponential autocorrelation function adopted in this study. A realization of the three-dimensional random fields is demonstrated in Fig. 2. To quantitatively describe the random field, Fig. 3 demonstrates the undrained shear strength along a vertical line for four realizations of random fields.

\section{Random finite element method}

The Random Finite Element Method (RFEM) is employed to simulate the behavior of a spudcan buried in spatially varied seabed subjected to various loading conditions (Li et al., 2016). The inverted conical spudcan model (shown in Fig. 4 ) is $18 \mathrm{~m}$ in diameter $(D)$ and $7.2 \mathrm{~m}$ in height. The spudcan is embedded in depth of $3 \mathrm{D}$ and modeled as a rigid body with loads and displacements relating to a reference point. The reference point is chosen at the center of the section of lowest maximum bearing area (see Fig. 4). A cylindrical soil model with $6 D$ in diameter and $6 D$ in height is adopted, which is found sufficient to avoid boundary effects. At the sides of the model, no horizontal movements are permitted while the base of the model is fixed in all three directions. The foundation-soil interaction is assumed to be bonded to simulate fully rough spudcan soil interaction (Zhang et al., 2011, 2012).

The three-dimensional mesh for the spudcan and soil models consist of nearly 48,000 first order hexahedral (C3D8) elements as shown in Fig. 4. Finer elements are applied close to the spudcan to ensure the accuracy of the analyses. This mesh is used to balance the accuracy and the cost of computational time. The generated random fields of the undrained shear strength can be mapped into the mesh to model the spatially varied strength.

400 realizations of random fields are generated for each seabed clay with a specific coefficient of variation $\left(\operatorname{COV}\left(s_{u}\right)\right)$. It has been proved the 400 realizations could ensure a maximum error of $3 \%$ of the average undrained shear strength ( $\mathrm{Li}$ et al., 2015a). The random finite element analysis is performed for each of the random fields to investigate the bearing capacity and failure mechanism of the spudcan foundation. The Monte-Carlo simulations are conducted to explore the effect of spatial variability. With five different $\operatorname{COV}\left(s_{\mathrm{u}}\right)$ (i.e., $\sigma_{\mathrm{s}} / \mu_{\mathrm{s}}$ ), there are 6000 simulations in this paper.

\section{Results}

\subsection{Model verification in uniform soils}

The model is verified by a spudcan in uniform soils with undrained shear strength of $10 \mathrm{kPa}$. When the embedded spudcan foundation is vertically displaced, the vertical bearing capacity would increase with the displacement until the ultimate bearing capacity $\left(V_{d e t}\right)$ is attained (as shown in Fig. 5). A dimensionless vertical bearing capacity factor $N_{c v}$ is defined as,

$N_{\mathrm{cv}}=\frac{V}{A \mu_{\mathrm{s}}}$

where $V$ is the vertical bearing capacity, $A$ is the cross-sectional area of the spudcan $\left(\pi D^{2} / 4\right), \mu_{\mathrm{s}}$ is the mean value of the undrained shear strength.

Fig. 5 shows the variation in vertical bearing capacity factor when the spudcan is pushed down in vertical direction. The bearing capacity 
a
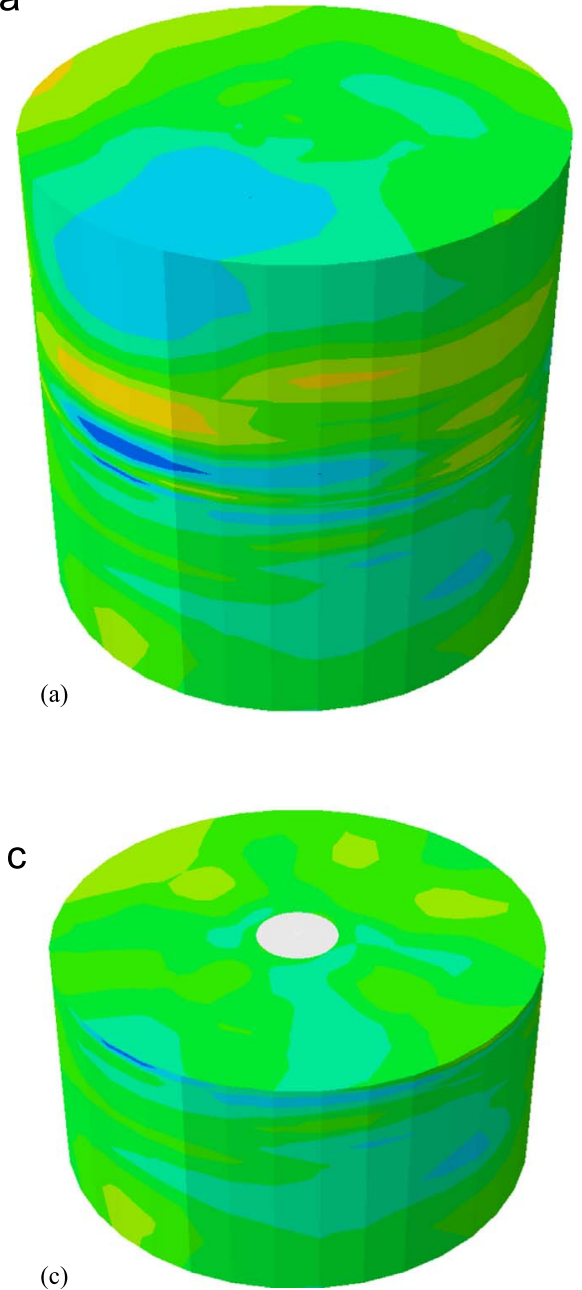

b
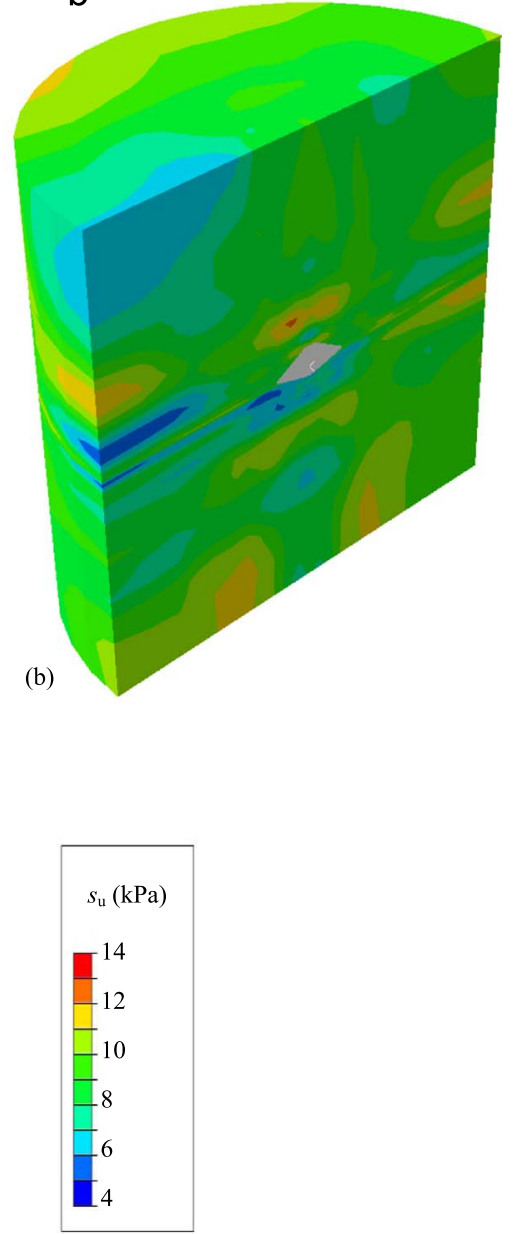

Fig. 2. A realization of three-dimensional random field for undrained shear strength: (a) cylindrical model (b) vertical slice (c) horizontal slice.

increases gradually with the vertical displacement of the spudcan $(d)$ and reaches an ultimate bearing capacity as the displacement approached $0.04 D$. The ultimate vertical bearing capacity factor is 13.20 . Martin and Randolph (2001) reported that the theoretical vertical ultimate bearing capacity factor for a thin plate embedded deeply in uniform soils is 13.11, which is close to the result in this study. The plastic zones in the surrounding soil corresponding to the displacements are also shown in Fig. 5. The plastic zones enlarge with the increasing displacement. Finally, the plastic zones form a continuous shear plane, indicating localized failure in the surrounding clay.

If the spudcan is subjected to a horizontal loading (or moment loading), a horizontal bearing capacity factor, $N_{c h}$ (or moment bearing capacity factor, $N_{c m}$ ), can be defined as,

$N_{c h}=\frac{H}{A \mu_{s}}$

$N_{c m}=\frac{M}{A D \mu_{s}}$

where $H$ and $M$ are the horizontal bearing capacity and moment bearing capacity, respectively.

The moment bearing capacity factor for the embedded spudcan in this study is 1.66 , which is close to the theoretical result for an embedded plate anchor, 1.57 (Elkhatib, 2006). The slight difference may be because that the geometry of the spudcan foundation is different from the plate anchor. The consistency between this study and the theoretical values confirms that the results from the finite element model are reliable.

\subsection{Bearing capacity in spatially varying seabed clay}

The spatial variability of the clay is modeled by random fields. The bearing capacity of the spudcan in each random field is investigated using the random finite element method. In the Monte-Carlo simulations, 400 realizations of random fields corresponding to a specific $\operatorname{COV}\left(s_{u}\right)$ resulted in 400 bearing capacity-displacement curves. Fig. 6 shows the variation in bearing capacity factors for the spudcan in 400 realizations of random fields with $\operatorname{COV}\left(s_{u}\right)$ of 0.3 . The ultimate vertical bearing capacity factors ranges from 8.13 to 17.65 (see Fig. 6a). The mean bearing capacity factor is 12.64 , which is smaller than that in uniform soils (i.e., 13.20). About $60 \%$ of the cases in spatially varying soils have smaller vertical bearing capacities than that in uniform soils. As the shear planes tend to find a path that cost the least energy they prone to go through the weaker soils in the random fields ( $\mathrm{Li}$ et al., 2015a). Hence the weaker soils that form the failure path lead to a lower meanbearing capacity. The results indicate that the spatial variability in the seabed clay can dramatically decrease the bearing capacity of the spudcan.

The horizontal and moment bearing capacity factors for the spudcan vary in a wide range as shown in Figs. $6 \mathrm{~b}$ and $6 \mathrm{c}$. The mean horizontal bearing capacity factor is 5.23 for the spudcan in the spatially varying soils, which is also smaller than that in the uniform soils. About $52 \%$ of the cases in spatially varying soils have smaller horizontal bearing capacities than that in uniform soils. The moment bearing capacity values in $57 \%$ of the simulations with random soils are smaller than that in uniform soils. 


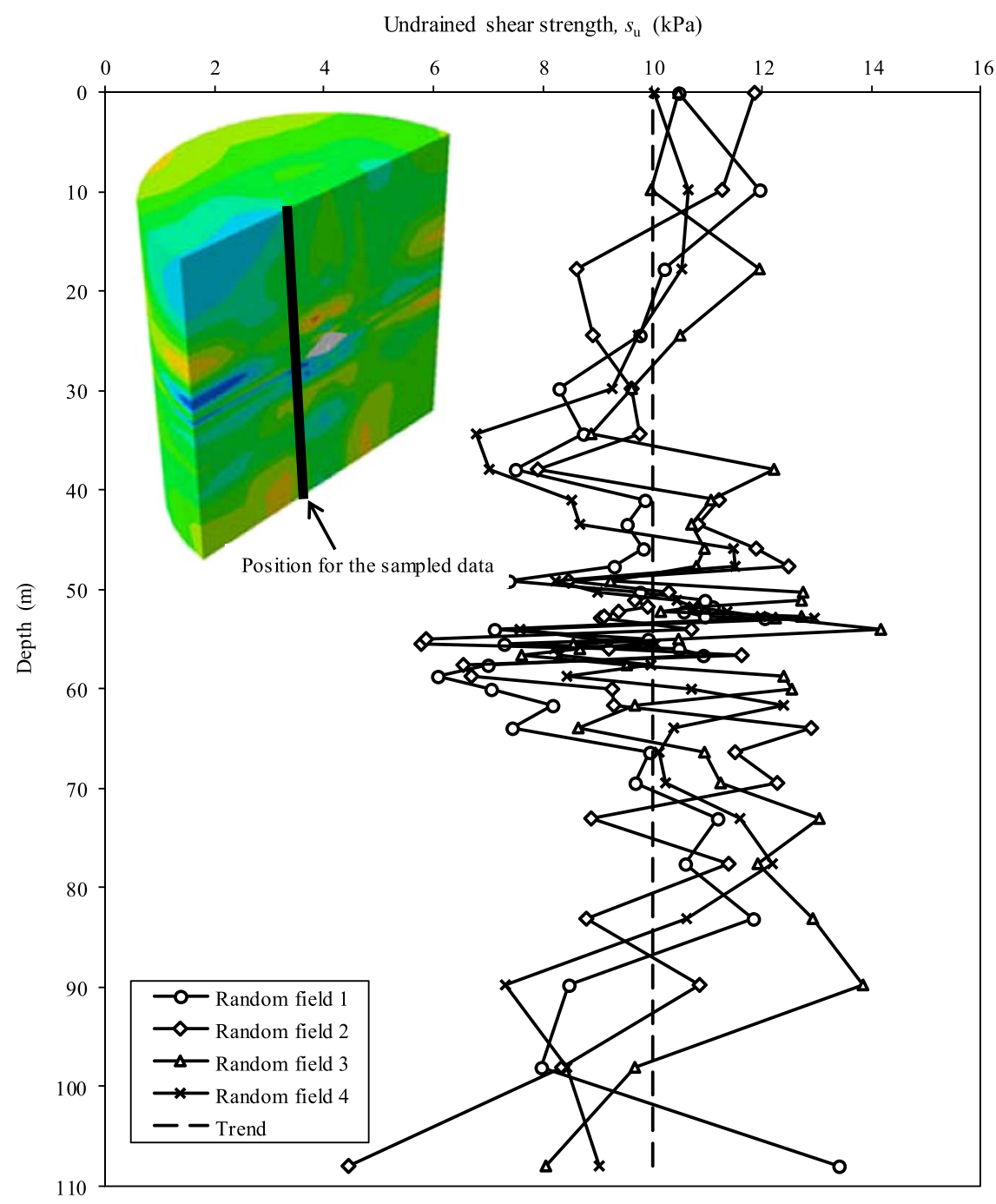

Fig. 3. Four typical simulations of random field for undrained shear strength.
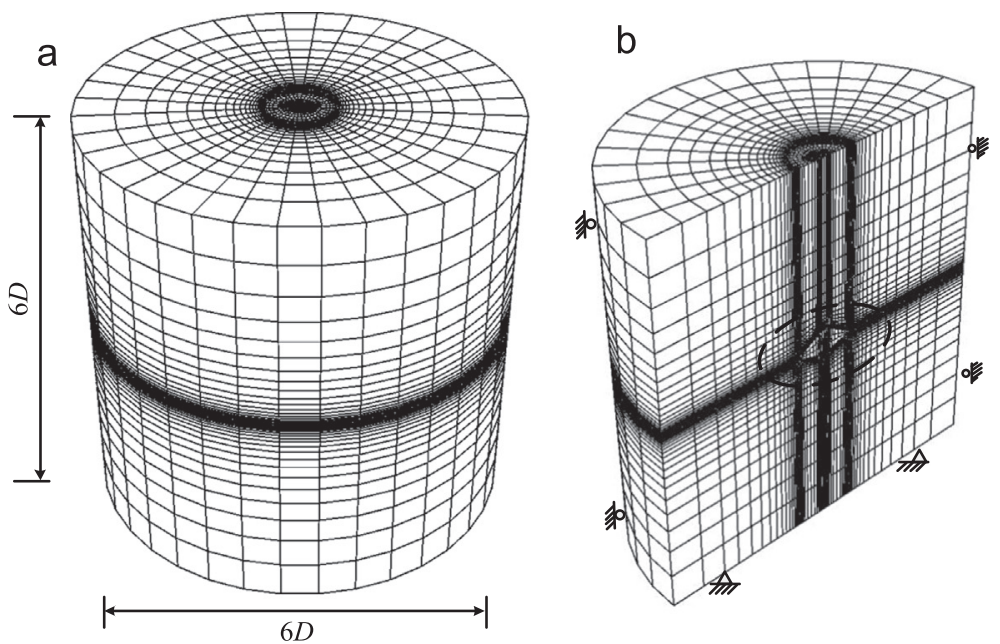

C

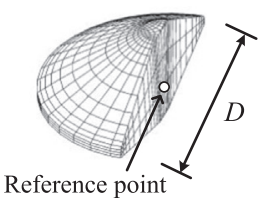

Fig. 4. Geometry of finite element soil model and spudcan foundation: (a) cylindrical soil model (b) half of the model (c) half of the spudcan model.

The influence of the coefficient of variation of the clay $\left(\operatorname{COV}\left(s_{u}\right)\right)$ on the bearing capacity is investigated in this study. The bearing capacity values in different directions are normalized by the corresponding bearing capacity in uniform soils to give normalized bearing capacities ( $V_{\text {norm }}, H_{\text {norm }}$ and $\left.M_{\text {norm }}\right)$ :
$V_{\text {norm }}=\frac{V_{\text {ran }}}{V_{\text {det }}}$

$$
H_{\text {norm }}=\frac{H_{\text {ran }}}{H_{\text {det }}}
$$




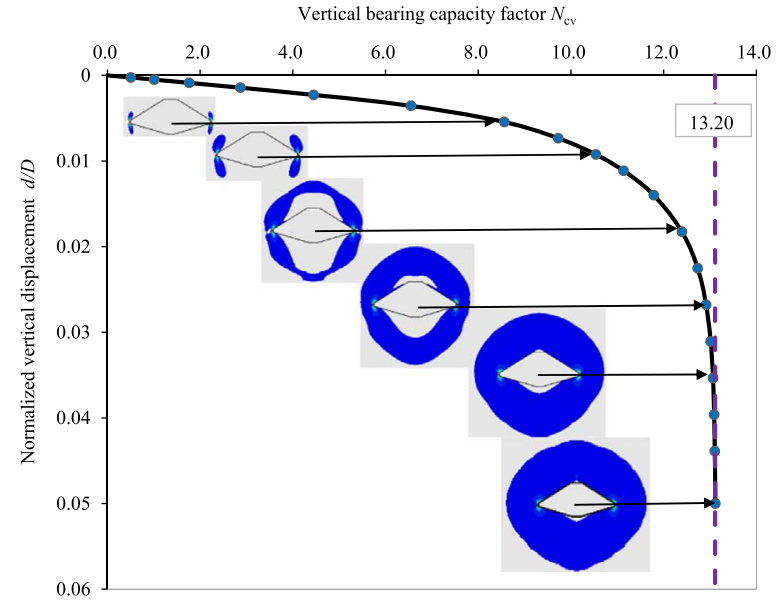

Fig. 5. Variation of vertical bearing capacity factor with the normalized vertical displacement.
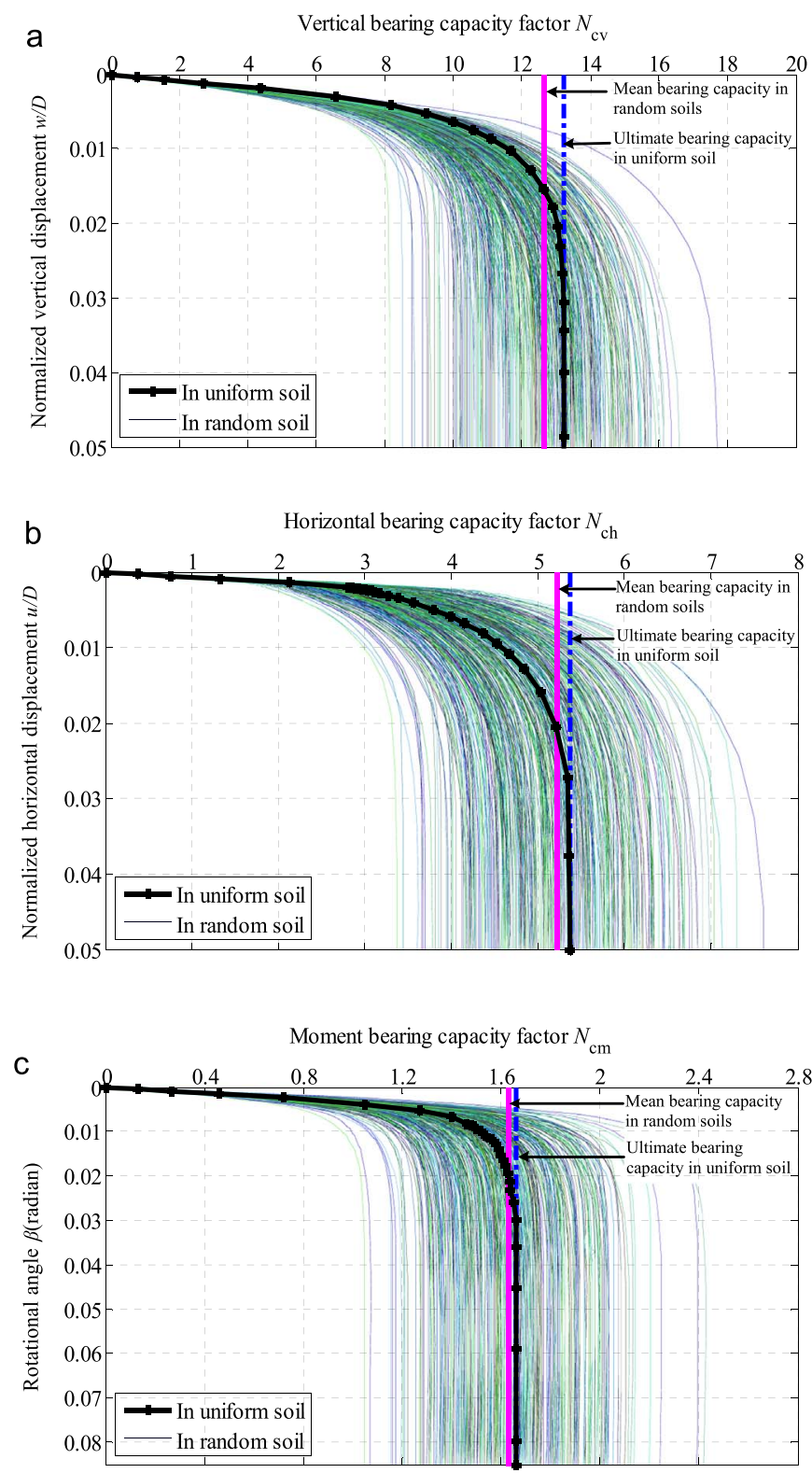

Fig. 6. Bearing capacity factor-displacement curves for: (a) vertically loaded spudcan (b) horizontally loaded spudcan (c) rotationally loaded spudcan (COV=0.3).
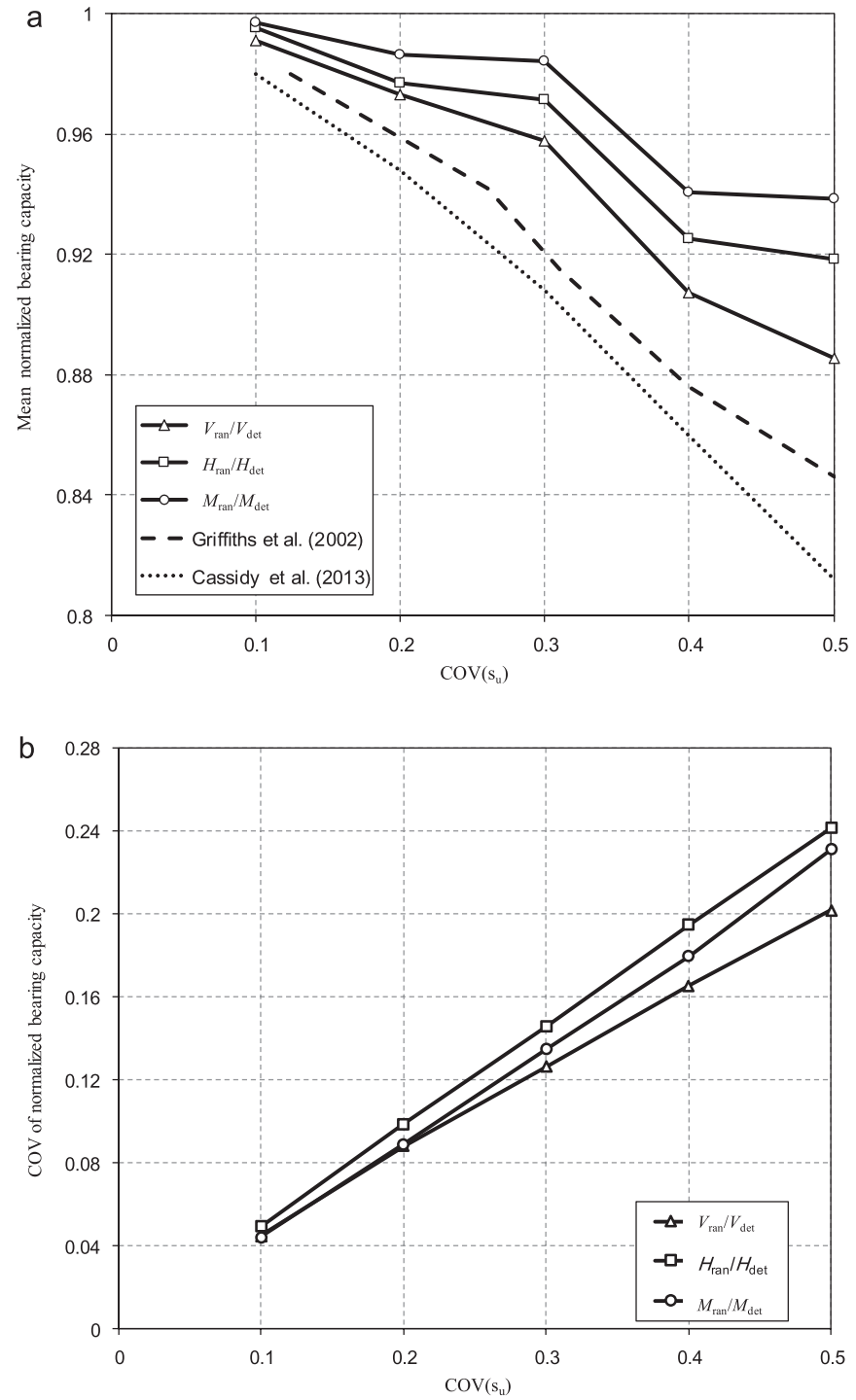

Fig. 7. Variation in: (a) mean normalized bearing capacity and (b) COV of normalized bearing capacity with $\mathrm{COV}\left(\mathrm{s}_{\mathrm{u}}\right)$.

$M_{\text {norm }}=\frac{M_{\text {ran }}}{M_{\text {det }}}$

where $V_{\text {ran }}, H_{\text {ran }}$ and $M_{\text {ran }}$ are the vertical, horizontal, and moment ultimate bearing capacity of the spudcan in spatially varied soils, respectively. $V_{\text {det }}, H_{\text {det }}$ and $M_{\text {det }}$ are the vertical, horizontal and moment ultimate bearing capacity of the spudcan in uniform soils. Fig. 7a shows the variation in the mean value of the normalized bearing capacity when the $\operatorname{COV}\left(s_{u}\right)$ of the seabed clay is changed. The mean normalized bearing capacity are smaller than unity, which indicates the mean bearing capacities in spatially varying soils are smaller than that in uniform soils. The mean of the vertical normalized bearing capacity values become smaller as the $\operatorname{COV}\left(s_{\mathrm{u}}\right)$ increases. The results indicate a larger variation in soil shear strength leads to a smaller mean vertical bearing capacity of spudcan foundations. This trend is similar to that for the vertical bearing capacity of strip foundations (Griffiths et al., 2002; Cassidy et al., 2013). The mean of the horizontal and moment normalized bearing capacity values also decrease with increasing $\operatorname{COV}\left(s_{\mathrm{u}}\right)$. The reduction in the vertical bearing capacity is more significant than the horizontal and moment bearing capacities.

The change of the coefficient of variation of the normalized bearing capacity with $\operatorname{COV}\left(s_{\mathrm{u}}\right)$ are shown in Fig. $7 \mathrm{~b}$. The COVs of the normalized bearing capacity in vertical, horizontal and moment directions 


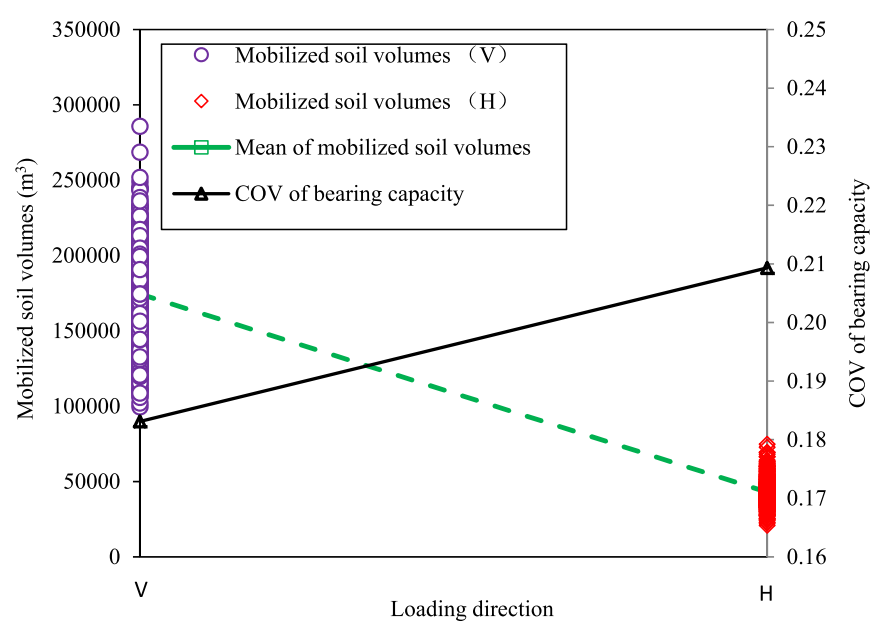

Fig. 8. Change of bearing capacity and the mobilized soil volumes at different loading directions $\left(\mathrm{COV}\left(s_{\mathrm{u}}\right)\right.$ of 0.3$)$.

increase with the coefficient of variation in undrained shear strength, $\operatorname{COV}\left(s_{\mathrm{u}}\right)$. A large scatter in the undrained shear strength leads to a large variation in the bearing capacity. It is interesting to note that the COVs of the bearing capacity in horizontal direction is larger than that in vertical direction. This difference might be caused by the smaller soil volumes that are mobilized when a foundation is loaded in horizontal directions. A soil element is defined as mobilized when its accumulated plastic shear strain is larger than 0.05 (Hossain and Randolph, 2009). The mobilized soil volumes for the spudcan in soils with $\operatorname{COV}\left(s_{\mathrm{u}}\right)$ of 0.3 are shown in Fig. 8. The mobilized soil volumes for the vertically loaded spudcan are always larger than those for the horizontally loaded spudcan. On the contrary, the COV of the vertical bearing capacity is smaller than the COV of the horizontal bearing capacity. A larger mobilized soil volume results in a stronger spatial averaging of the random soil, and in turn, a smaller COV in the bearing capacity.

\subsection{Mobilized shear strength}

The trajectory of a slip plane in spatially varying soils is generally different from that in uniform soils (Li et al., 2015a). The bearing capacity of a spudcan is closely related with the trajectory and the soil shear strength along the slip plane. Hence the shear strength mobilized along the slip plane is fundamentally related to the bearing capacity (Ching and Phoon, 2013a, 2013b). If the theoretical vertical bearing capacity factor for the spudcan in uniform soils is used, the ultimate vertical bearing capacity of the spudcan in spatially varying soils only varies with the mobilized shear strength as shown in Eq. (7),

$s_{u v}^{m}=\frac{V_{r a n}}{A N_{c v}^{u}}$

where $s_{u v}^{m}$ is the mobilized shear strength when the spudcan is vertically displaced; $V_{\text {ran }}$ is the ultimate vertical bearing capacity of the spudcan in a realization of random fields; $N_{c v}^{u}$ is the theoretical ultimate bearing capacity factor in vertical direction (i.e. 13.11); $A$ is the widest bearing area of the spudcan. The mobilized shear strength can be defined in a similar way when the spudcan is loaded horizontally and rotationally,

$s_{u \mathrm{~h}}^{m}=\frac{H_{r a n}}{A N_{c h}^{u}}$

$s_{u m}^{m}=\frac{M_{r a n}}{A D N_{c m}^{u}}$

where $s_{u h}^{m}$ and $s_{u m}^{m}$ are the mobilized shear strength when considering the horizontal load and moment, respectively; $N_{c h}^{u}$ and $N_{c m}^{u}$ are the theoretical ultimate bearing capacity factor in horizontal and rotational a

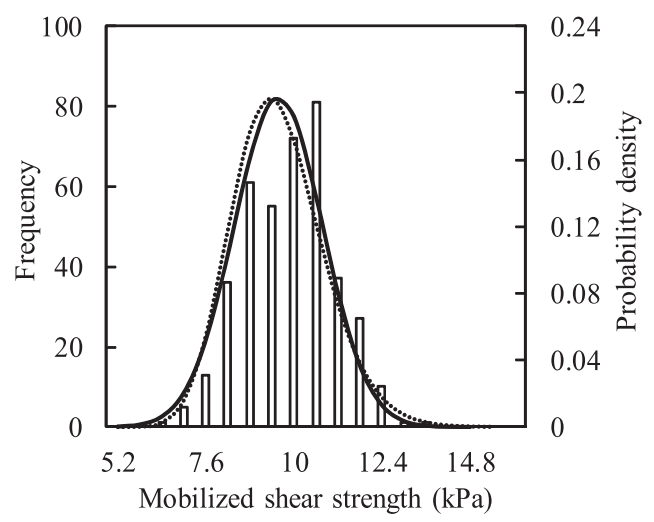

b
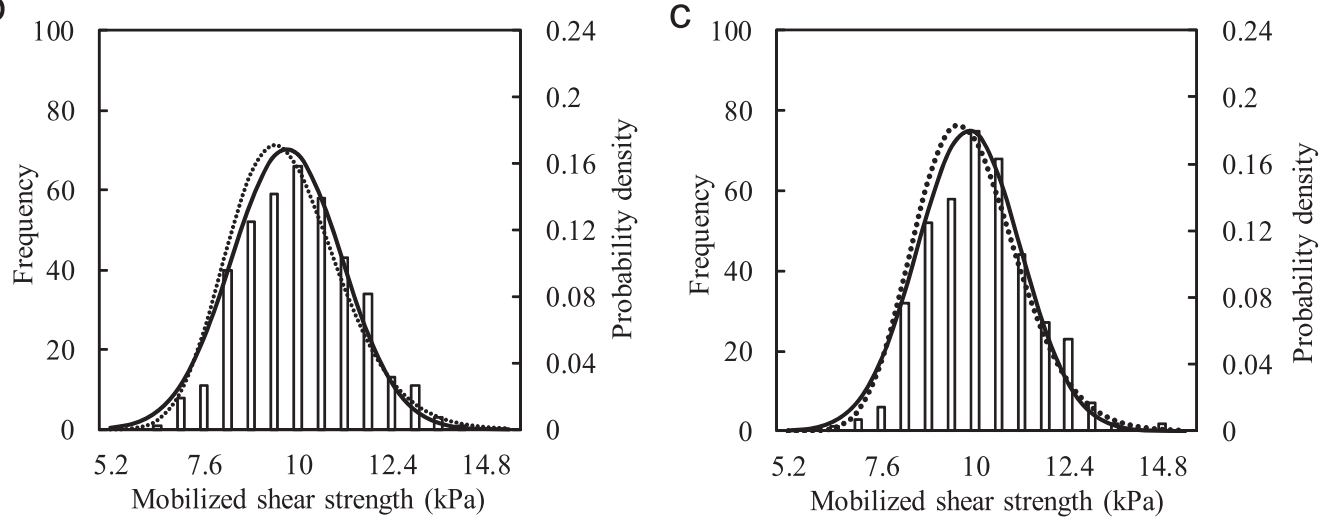

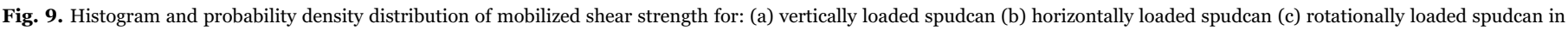
soils with $\operatorname{COV}\left(\mathrm{s}_{\mathrm{u}}\right)$ of 0.3 . 


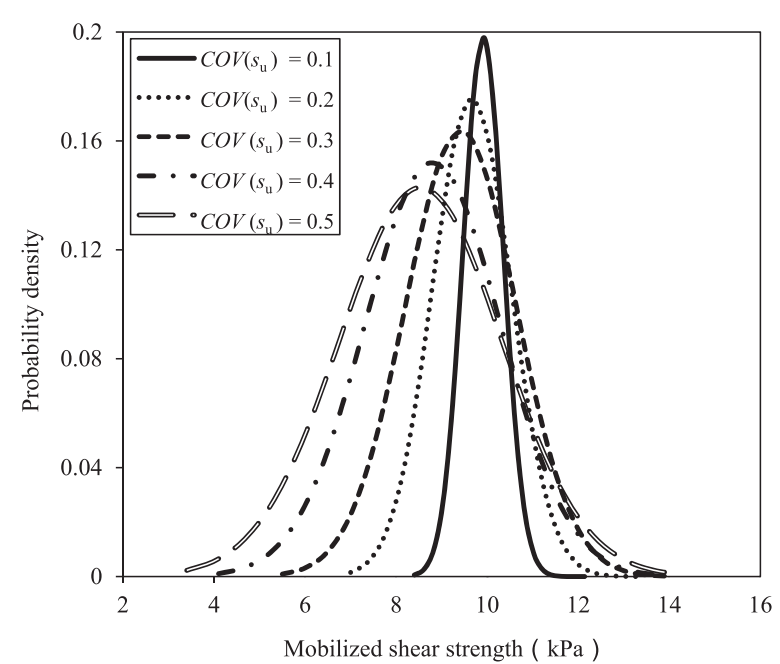

Fig. 10. Probability density distribution of mobilized shear strength for a vertically displaced foundation with different $\operatorname{COV}\left(\mathrm{s}_{\mathrm{u}}\right)$.

directions, respectively.

The mobilized shear strength can then be calculated for each realization of the random fields. The histogram of the mobilized shear strength for the vertically displaced spudcan in soils with $\operatorname{COV}\left(s_{u}\right)$ of 0.3 is shown in Fig. 9a. The mobilized shear strengths from different random fields distribute in a wide range from $5.2 \mathrm{kPa}$ to $14.8 \mathrm{kPa}$, with an average value of $9.58 \mathrm{kPa}$. Figs. $9 \mathrm{~b}$ and $9 \mathrm{c}$ show the histograms of the mobilized shear strength when the spudcan is displaced horizontally or rotationally. The average mobilized shear strength is $9.72 \mathrm{kPa}$ for horizontally displaced spudcan and $9.84 \mathrm{kPa}$ for rotationally displaced spudcan. Normal distribution and Log-normal distribution are used to fit the histograms as shown in Fig. 9. Chi-square test indicates that the normal distribution performs better. Hence normal distribution is used in the fitting of the mobilized shear strength for soils with different $\operatorname{COV}\left(s_{\mathrm{u}}\right)$.

Fig. 10 shows the probability density function of the mobilized shear strength for soils with different $\operatorname{COV}\left(s_{u}\right)$. When $\operatorname{COV}\left(s_{\mathrm{u}}\right)$ is small, the mean mobilized shear strength is concentrated and approaches the input mean undrained shear strength (i.e., $10 \mathrm{kPa}$ ). The mean mobilized shear strength decreases as the $\operatorname{COV}\left(s_{\mathrm{u}}\right)$ increases. The variation in the mobilized shear strength is higher for a larger $\operatorname{COV}\left(s_{u}\right)$. The relationship between the mobilized shear strength and the input shear strength is listed in Table 1 . The results indicate that the statistical mean and COV of mobilized shear strength vary significantly with the coefficient of variation of the undrained shear strength in seabed clay. The characteristic value of shear strength for a spatially varying soil is closely related with the mobilized shear strength.

\subsection{Characteristic value of the undrained shear strength}

A characteristic value of the soil strength is required in the design of a geotechnical structure. In current practices, the characteristic value

Table 1

Relationship between the mobilized shear strength with the input shear strength.

\begin{tabular}{lllllll}
\hline $\begin{array}{l}\text { Input shear } \\
\text { strength } \\
\left(\mu_{\mathrm{s}}=10 \mathrm{kPa}\right)\end{array}$ & $\begin{array}{l}\mu\left(s_{u v}^{m}\right) \\
(\mathrm{kPa})\end{array}$ & $\operatorname{COV}\left(s_{u v}^{m}\right)$ & $\begin{array}{l}\mu\left(s_{u h}^{m}\right) \\
(\mathrm{kPa})\end{array}$ & $\operatorname{COV}\left(s_{u h}^{m}\right)$ & $\begin{array}{l}\mu\left(s_{u m}^{m}\right) \\
(\mathrm{kPa})\end{array}$ & $\operatorname{COV}\left(s_{u m}^{m}\right)$ \\
\cline { 2 - 7 } & 9.91 & 0.045 & 9.95 & 0.049 & 9.97 & 0.044 \\
\hline $\operatorname{COV}\left(s_{\mathrm{u}}\right)=0.1$ & 9.73 & 0.088 & 9.80 & 0.102 & 9.86 & 0.089 \\
$\operatorname{COV}\left(s_{\mathrm{u}}\right)=0.2$ & 9.58 & 0.126 & 9.72 & 0.146 & 9.84 & 0.135 \\
$\operatorname{COV}\left(s_{\mathrm{u}}\right)=0.3$ & 9.07 & 0.166 & 9.25 & 0.195 & 9.41 & 0.180 \\
$\operatorname{COV}\left(s_{\mathrm{u}}\right)=0.4$ & 8.85 & 0.202 & 9.18 & 0.242 & 9.39 & 0.231 \\
$\operatorname{COV}\left(s_{\mathrm{u}}\right)=0.5$ & 8.18 & & & & \\
\hline
\end{tabular}

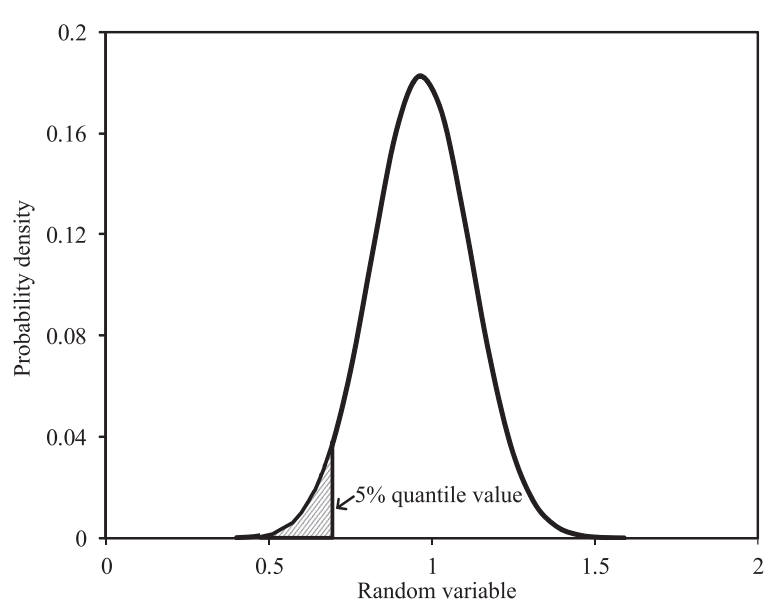

Fig. 11. The significance of $5 \%$ quantile of probability density distribution.

are often set as $\left(\mu_{\mathrm{s}}-k \cdot \sigma_{\mathrm{s}}\right)$ where $k$ is a constant. However, the probability of failure resulted by using these characteristic values for soils with different $\operatorname{COV}\left(s_{\mathrm{u}}\right)$ remains unclear (Paikowsky, 2002; Phoon and Ching, 2015). Eurocode 7 recommends that characteristic values should be derived such that the calculated probability of a worse value governing the occurrence of a limit state is not greater than $5 \%$ (British Standards Institute, 2002). The following paragraphs will discuss the characteristic value from the viewpoint of the probability of failure.

According to Eqs. (7)-(9) the probability density function for the bearing capacity has the same trend as that for the mobilized shear strength shown in Fig. 10. Hence, the 5\% quantile value (as shown in Fig. 11) in the distribution of bearing capacity is correspondence to the $5 \%$ quantile value in the mobilized shear strength. For the clay with $\operatorname{COV}\left(s_{\mathrm{u}}\right)$ of 0.1 , the mobilized shear strength corresponding to $5 \%$ quantile is $9.18 \mathrm{kPa}$. The result indicates a characteristic value of $9.18 \mathrm{kPa}$ ensures the probability of failure in the specific soils is not greater than $5 \%$. This characteristic value is equal to $\left(\mu_{\mathrm{s}}-0.82 \cdot \sigma_{\mathrm{s}}\right)$ where $\mu_{\mathrm{s}}$ is $10 \mathrm{kPa}$ and $\sigma_{\mathrm{s}}$ is $1 \mathrm{kPa}$ in this case.

The characteristic value corresponding to $5 \%$ quantile in the soils with higher $\operatorname{COV}\left(s_{\mathrm{u}}\right)$ becomes smaller. When the $\operatorname{COV}\left(s_{\mathrm{u}}\right)$ is 0.5 , the characteristic value is $5.91 \mathrm{kPa}$. This value is approximately equal to $\left(\mu_{\mathrm{s}}-0.82 \cdot \sigma_{\mathrm{s}}\right)$ where $\mu_{\mathrm{s}}$ is $10 \mathrm{kPa}$ and $\sigma_{\mathrm{s}}$ is $5 \mathrm{kPa}$. The characteristic values corresponding to $5 \%$ quantile value of mobilized shear strength for soils with different $\operatorname{COV}\left(s_{\mathrm{u}}\right)$ are summarized in Table 2. The results indicate a smaller characteristic value should be used for a larger $\operatorname{COV}\left(s_{\mathrm{u}}\right)$ although the mean shear strength is the same. The values of $\left(\mu_{\mathrm{s}}-0.82 \cdot \sigma_{\mathrm{s}}\right)$ for soils with different $\operatorname{COV}\left(s_{\mathrm{u}}\right)$ are also listed in Table 2. This characteristic value is close to the $5 \%$ quantile value of the mobilized shear strength.

If the seabed is simplified as a uniform soil and the value of $\left(\mu_{\mathrm{s}}-\right.$ $0.82 \cdot \sigma_{\mathrm{s}}$ ) is taken as its characteristic value, a bearing capacity of the spudcan in this uniform soil can be obtained. For example, the bearing capacity of a spudcan in uniform soils with characteristic shear strength of $5.91 \mathrm{kPa}$ is $25.52 \mathrm{MN}$. This bearing capacity value corresponds to $4 \%$ quantile value if the spatial variability of the soil is considered. Fig. 12 shows the histogram and probability distribution

Table 2

Comparison between the $5 \%$ quantile values of mobilized shear strength and $\left(\mu_{\mathrm{s}}-0.82 \sigma_{\mathrm{s}}\right)$.

\begin{tabular}{lll}
\hline $\operatorname{COV}\left(\mathbf{s}_{\mathbf{u}}\right)$ & $\begin{array}{l}\text { 5\% quantile value of mobilized shear } \\
\text { strength }(\mathbf{k P a})\end{array}$ & $\begin{array}{l}\boldsymbol{\mu}_{\mathbf{s}}-\mathbf{0 . 8 2} \boldsymbol{\sigma}_{\mathbf{s}} \\
(\mathbf{k P a})\end{array}$ \\
\hline 0.1 & 9.18 & 9.18 \\
0.2 & 8.32 & 8.36 \\
0.3 & 7.59 & 7.54 \\
0.4 & 6.60 & 6.72 \\
0.5 & 5.91 & 5.90 \\
\hline
\end{tabular}




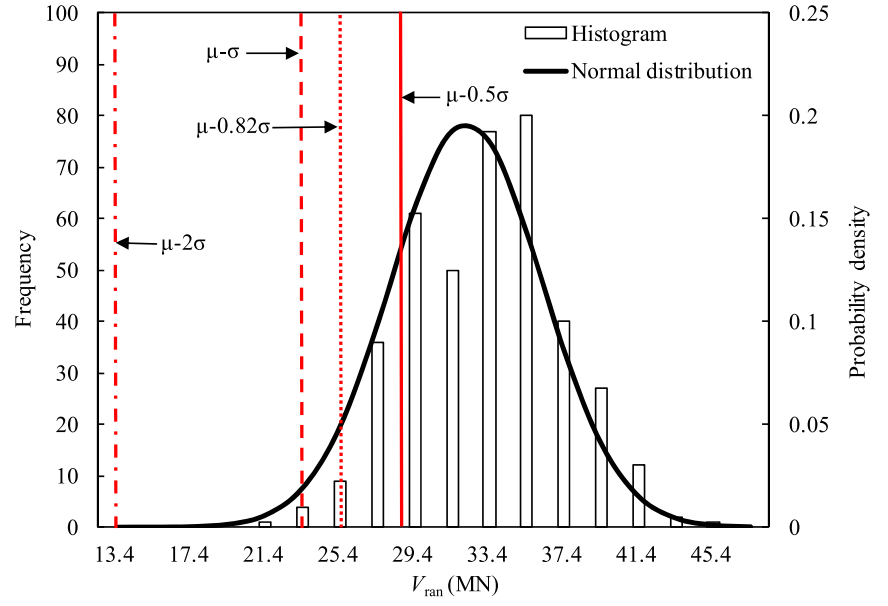

Fig. 12. The histogram and probability density distribution of vertical bearing capacity in soils with $\operatorname{COV}\left(s_{\mathrm{u}}\right)$ of 0.3 .

Table 3

Failure probabilities for various characteristic shear strengths.

\begin{tabular}{lllll}
\hline $\operatorname{COV}\left(\boldsymbol{s}_{\mathbf{u}}\right)$ & $\boldsymbol{\mu}_{\mathbf{s}}-\mathbf{0 . 5} \boldsymbol{\sigma}_{\mathbf{s}}$ & $\boldsymbol{\mu}_{\mathbf{s}}-\mathbf{0 . 8 2} \boldsymbol{\sigma}_{\mathbf{s}}$ & $\boldsymbol{\mu}_{\mathbf{s}}-\boldsymbol{\sigma}_{\mathbf{s}}$ & $\boldsymbol{\mu}_{\mathbf{s}}-\mathbf{2} \boldsymbol{\sigma}_{\mathbf{s}}$ \\
\hline 0.1 & $15 \%$ & $4 \%$ & $2 \%$ & $0.0005 \%$ \\
0.2 & $18 \%$ & $5 \%$ & $2 \%$ & $0.0005 \%$ \\
0.3 & $17 \%$ & $4 \%$ & $1 \%$ & $0.0002 \%$ \\
0.4 & $23 \%$ & $5 \%$ & $2 \%$ & $0.0001 \%$ \\
0.5 & $21 \%$ & $4 \%$ & $1 \%$ & - \\
\hline
\end{tabular}

of the ultimate vertical bearing capacity for a spudcan embedded when $\operatorname{COV}\left(s_{\mathrm{u}}\right)$ is 0.3 . If a characteristic value of $\left(\mu_{\mathrm{s}}-\sigma_{\mathrm{s}}\right)$ are used, the corresponding bearing capacity values obtained from the uniform soils with constant shear strength of $\left(\mu_{\mathrm{s}}-\sigma_{\mathrm{s}}\right)$ are also shown in the figure. Results show that when the characteristic shear strength is taken as $\left(\mu_{\mathrm{s}}-2 \sigma_{\mathrm{s}}\right)$ the bearing capacity is $13.40 \mathrm{MN}$. The probability that the bearing capacity of the spudcan in the random soils is less than 13.40 MN is $2 \times 10^{-6}$.

To further investigate the probability of failure for the characteristic values for soils with different $\operatorname{COV}\left(s_{\mathrm{u}}\right)$, finite element analyses are conducted for simplified uniform soils with characteristic shear strengths of $\left(\mu_{\mathrm{s}}-0.5 \sigma_{\mathrm{s}}\right),\left(\mu_{\mathrm{s}}-0.82 \sigma_{\mathrm{s}}\right),\left(\mu_{\mathrm{s}}-\sigma_{\mathrm{s}}\right)$ and $\left(\mu_{\mathrm{s}}-2 \sigma_{\mathrm{s}}\right)$. Table 3 shows the quantile values of the bearing capacity if the characteristic values are employed. For example, if $\left(\mu_{\mathrm{s}}-\sigma_{\mathrm{s}}\right)$ is set as the characteristic value of a soil with lognormally distributed undrained shear strength with mean value of $10 \mathrm{kPa}$ and standard deviation of 0.3 , the probability of failure for the spudcan is not greater than $1 \%$. When a characteristic value of $\left(\mu_{\mathrm{s}}-0.5 \sigma_{\mathrm{s}}\right)$ is used, the probability of failure is about $15 \%$ for soils with $\operatorname{COV}\left(s_{\mathrm{u}}\right)$ of 0.1 and is about $23 \%$ for soils with $\operatorname{COV}\left(s_{\mathrm{u}}\right)$ of 0.4 . When a characteristic value of $\left(\mu_{\mathrm{s}}-\sigma_{\mathrm{s}}\right)$ is chosen, the probability of failure is about $1-2 \%$. When a characteristic value is set as $\left(\mu_{\mathrm{s}}-2 \sigma_{\mathrm{s}}\right)$, the probability of failure is $1 \times 10^{-6}$ for soils with $\operatorname{COV}\left(s_{\mathrm{u}}\right)$ of 0.4 . The results indicate a characteristic value of $\left(\mu_{\mathrm{s}}-\sigma_{\mathrm{s}}\right)$ is capable to ensure the requirement of $5 \%$ quantile value in Eurocode 7 . The probability of failure is on the order of magnitude of $10^{-6}$ if a characteristic value of $\left(\mu_{\mathrm{s}}-2 \sigma_{\mathrm{s}}\right)$ is adopted. These conclusions are obtained based on the analyses of the embedded spudcan, and need further investigation for other geotechnical structures and soils with different autocorrelation functions.

\section{Conclusions}

The bearing capacities of a spudcan subjected to vertical, horizontal and moment displacements are investigated considering the spatial variability of the seabed clay. The characteristic value of the undrained shear strength used for design is discussed in terms of the mobilized shear strength. The following conclusions can be drawn:

(1) The bearing capacity of a spudcan in spatially varying seabed clay varied with the spatial pattern of the undrained shear strength. The mean bearing capacity decreases as the coefficient of variation of the undrained shear strength of the seabed clay increases. The reduction in the vertical bearing capacity is more significant than the horizontal bearing capacity and moment bearing capacity as $\operatorname{COV}\left(s_{\mathrm{u}}\right)$ increases.

(2) The coefficient of variation of the horizontal bearing capacity is larger than that in vertical bearing capacity. The reason is that more soils are mobilized when the spudcan moved vertically, which leads to stronger averaging effects and smaller variation in the vertical bearing capacity.

(3) A characteristic value of $\left(\mu_{\mathrm{s}}-\sigma_{\mathrm{s}}\right)$ is capable to ensure the probability of failure of the spudcan embedded in the spatially varying seabed clay is not greater than $5 \%$. The probability of failure by adopting a characteristic value of $\left(\mu_{\mathrm{s}}-2 \sigma_{\mathrm{s}}\right)$ is on the order of magnitude of $10^{-6}$. These conclusions are obtained for the embedded spudcan. Further investigations are needed for other geotechnical structures and soils with different autocorrelation functions.

\section{Acknowledgements}

The authors would like to acknowledge the support of Natural Science Foundation of China (Grant nos. 51379053, 51679060) and the Youth Innovation Promotion Association CAS.

\section{References}

API Recommended Practice 2GEO, 2011. Geotechnical and Foundation Design Considerations. American Petroleum Institute, Washington, DC, USA.

Baecher, G.B., Christian, J.T., 2003. Reliability and Statistics in Geotechnical Engineering. Wiley, Chichester, U.K..

British Standards Institute, 2002. Eurocode: Basis of Structural Design (EN 1990:2002). British Standards Institute, London.

Brennan, R., Diana, H., Stonor, R.W.P., Hoyle, M.J.R., Cheng, C.P., Roper, R., 2006. Installing jackups in punch-through-sensitive clays. Offshore Technology Conference, 1-4 May, Houston, Texas, USA, OTC-18268.

Cassidy, M.J., Uzielli, M., Tian, Y., 2013. Probabilistic combined loading failure envelopes of a strip footing on spatially variable soil. Comput. Geotech. 49, 191-205.

Cheon, J.Y., Gilbert, R.B., 2014. Modeling spatial variability in offshore geotechnical properties for reliability-based foundation design. Struct. Saf. 49, 18-26.

Ching, J., Phoon, K.K., 2011. A quantile-based approach for calibrating reliability-based partial factors. Struct. Saf. 33 (4-5), 275-285.

Ching, J., Phoon, K.K., 2013a. Mobilized shear strength of spatially variable soils under simple stress states. Struct. Saf. 41 (3), 20-28.

Ching, J., Phoon, K.K., 2013b. Probability distribution for mobilised shear strengths of spatially variable soils under uniform stress states. Assessment and Management of Risk for Engineered Systems and Geohazards, Georisk. http://dx.doi.org/10.1080/ 17499518.2013 .801273$.

Elkhatib, S., 2006. The Behaviour of Drag-in Plate Anchors in Soft Cohesive Soils (Ph.D. thesis). Univ. of Western Australia, Perth, Australia.

Fenton, G.A., Griffiths, D.V., 2008. Risk Assessment in Geotechnical Engineering. John Wiley \& Sons, Hoboken, NJ.

Gao, F.P., Li, J.H., Qi, W.G., Hu, C., 2015. On the instability of offshore foundations: theory and mechanism. Sci. China-Phys., Mech. Astron. 58 (12), 124701.

Griffiths, D.V., Fenton, G.A., 2001. Bearing capacity of spatially random soil: the undrained clay Prandtl problem revisited. Géotechnique 51 (4), 351-359.

Griffiths, D.V., Fenton, G.A., Manoharan, N., 2002. Bearing capacity of rough rigid strip footing on cohesive soil: probabilistic study. J. Geotech. Geoenviron. Eng. 128 (9), 743-755.

Hossain, M.S., Randolph, M.F., 2009. Effect of strain rate and strain softening on the penetration resistance of Spudcan foundations on clay. Int. J. Geomech. 9 (3), $122-132$.

Hossain, M.S., Randolph, M.F., 2010. Deep-penetrating spudcan foundations on layered clays: centrifuge tests. Géotechnique 60 (3), 157-170.

Huang, J., Lyamin, A.V., Griffiths, D.V., Krabbenhoft, K., Sloan, S.W., 2013. Quantitative risk assessment of landslide by limit analysis and random fields. Comput. Geotech. $53,60-67$.

International Organization for Standardization (ISO), 2012. Petroleum and Natural Gas Industries-Site Specific Assessment of Mobile Offshore Units-Part 1: Jack-ups, International Standard ISO 19905-1:2012.

Lacasse, S., de Lamballerie, J.Y., 1995. Statistical treatment of CPT data. Proceedings CPT95. Linkøping, Sweden.

Lacasse, S., Nadim, F., 1996. Uncertainties in characterizing soil properties. Uncertainty 
in the Geologic Environment: From Theory to Practice ASCE Geotechnical Special Publication 58. ASCE, Reston, pp. 49-75.

Li, J., Tian, Y., Cassidy, M.J., 2015a. Failure mechanism and bearing capacity of footings buried at various depths in spatially random soil. J. Geotech. Geoenviron. Eng. 141 (2), 04014099.

Li, J.H., Uzielli, M., Cassidy, M.J., 2015b. Uncertainty-based characterization of Piezocone and T-bar data for the Laminaria offshore site. In: Proceedings of the 3rd International Symposium on Frontiers in Offshore Geotechnics, ISFOG 2015, Oslo, Norway.

Li, J.H., Zhou, Y., Zhang, L.L., Tian, Y., Cassidy, M.J., Zhang, L.M., 2016. Random finite element method for spudcan foundations in spatially variable soils. Eng. Geol. 205, $146-155$.

Martin, C.M., Randolph, M., 2001. Applications of lower and upper bound theorems of plasticity to collapse of circular foundations. Proc., 10th Int. Conf. on Computer Methods and Advances in Geomechanics, Vol. 2, A.A. Balkema, Netherlands, pp. 1417-1428.

Menzies, D., Roper, R., 2008. Comparison of jackup rig spudcan penetration methods in clay. Proceedings, Offshore Technology Conference, Houston, OTC 19545.

Paikowsky, S.G., 2002. Load and resistance factor design (LRFD) for deep foundations. In: Proceedings, international workshop on foundation design codes and soil investigation in view of international harmonization and performance based design, Tokyo, Japan; 2002. pp. 59-94.
Phoon, K.K., Ching, J., 2015. Is there anything better than LRFD for simplified geotechnical RBD? In: Proceedings of the 5th International Symposium on Geotechnical Safety and Risk (ISGSR), pp. 13-16, Rotterdam, Netherlands.

Phoon, K.K., Kulhawy, F.H., 1999. Characterization of geotechnical variability. Can Geotech. J. 36 (4), 612-624.

Tang, W.H., 1979. Probabilistic evaluation of penetration resistances. J. Geotech. Eng. Div. 105 (10), 173-1191.

Van Dijk, B.F.J., Yetginer, A.G., 2015. Findings of the ISSMGE jack-up leg penetration prediction event. In: Meyer (Ed.), Frontiers in Offshore Geotechnics III. Taylor and Francis Group, London, 1267-1274.

Vanmarcke, E.H., 1977. Probabilistic modeling of soil profiles. J. Geotech. Eng. Div. 103, $1227-1246$.

Wride, C.E., Mcroberts, E.C., Robertson, P.K., 1999. Reconsideration of case histories for estimating undrained shear strength in sandy soils. Can. Geotech. J. 36 (36), 907-933.

Young, A.G., Remmes, B.D., Meyer, B.J., 1984. Foundation performance of offshore jackup drilling rigs. J. Geotech. Eng. 110 (7), 841-859.

Zhang, Y., Bienen, B., Cassidy, M.J., Gourvenec, S., 2011. The undrained bearing capacity of a spudcan foundation under combined loading in soft clay. Mar. Struct. 24 (4), 459-477.

Zhang, Y., Cassidy, M.J., Bienen, B., 2012. Elastic stiffness coefficients for an embedded spudcan in clay. Comput. Geotech. 42 (5), 89-97. 